\title{
Char syndrome
}

INSERM

\section{Source}

INSERM. (1999). Orphanet: an online rare disease and orphan drug data base. Char syndrome. ORPHA:46627

A rare, genetic, multiple congenital anomalies/dysmorphic syndrome characterized by the triad of patent ductus arteriosus (PDA), facial dysmorphism (wide-set eyes, downslanting palpebral fissures, mild ptosis, flat midface, flat nasal bridge and upturned nasal tip, short philtrum with a triangular mouth, and thickened, everted lips) and hand anomalies (aplasia or hypoplasia of the middle phalanges of the fifth fingers). 